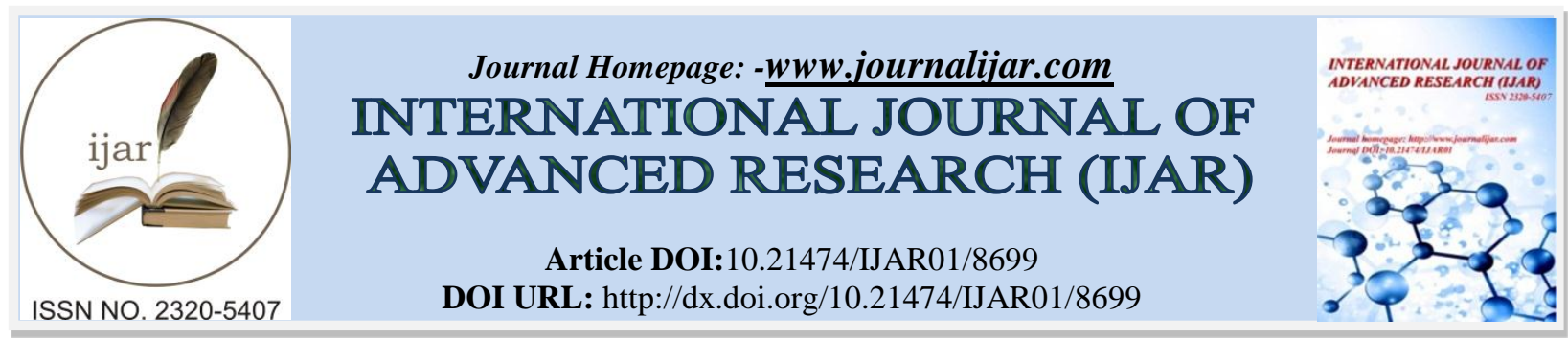

RESEARCH ARTICLE

\title{
EFFECT OF OPERATIONAL GOALS AND OBJECTIVES ON IMPLEMENTATION OF NHIS IN GHANA AND NIGERIA.
}

\author{
Busayo Olayinka, Michael A. Oni, Gift U. Ntiwunka and Michael I. Ogu. \\ Department of Political Science and Public Administration, Veronica Adeleke School of Social Sciences, Babcock \\ University, Ilishan-Remo, Ogun State, Nigeria.
}

\section{Manuscript Info}

Manuscript History

Received: 15 January 2019

Final Accepted: 17 February 2019

Published: March 2019

Key words:-

Implementation, NHIS, Objectives,

Operations, Services delivery.

\begin{abstract}
National Health Insurance Scheme (NHIS) was introduced in Ghana and Nigeria in 2003 and 2005 respectively. The primary objectives of the scheme was to ensure the delivery of quality health care to the citizens at affordable rates, to prevent untimely date as a result of inability to pay for health services in the two countries. However, the implementation of the Scheme had fallen below expectation as majority of the citizens are not enrolled in the NHIS in both countries. The study therefore examined the effect of the Objectives and operations of NHIS on its implementation in both countries. Survey design was adopted. The population of the study was 4,786,990 enrollees of NHIS in both countries. Sample size of 400 was determined using Taro Yamane formula. Respondents were selected from and three regions in Ghana (Ashanti, Brong-Ahafo, and Greater Accra regions) and five states in Nigeria (Lagos, Abuja, Edo, Imo and Ogun States). Questionnaire was the instrument of data collection and data were analyzed using descriptive and inferential statistics. The study found that objectives and operations of NHIS had a significant influence on its implementation ( $\left.\beta=.453, R^{2}=0.205, p<.05\right)$. The study concluded that the objectives and operations of NHIS affected the implementation of the scheme in Ghana and Nigeria.
\end{abstract}

Copy Right, IJAR, 2019,. All rights reserved.

\section{Introduction:-}

Healthy population and indeed work force are indispensable tools for rapid socio-economic and sustainable development the world over. Despite this indisputable fact, in Nigeria like most African countries, the provision of quality, accessible and affordable healthcare remains a serious problem (WHO, 2017a; Oba, 2015; Omoruan, Bamidele \& Philips, 2014). This is because the health sector is perennially faced with gross shortage of personnel (WHO, 2017a), inadequate and out-dated medical equipment (Yohesor, 2014; Johnson \&Stockpot, 2016), poor funding (WHO, 2017a\&b), policies inconsistence (Omoruan, Bamidele\& Philips, 2014) and corruption (Oba, 2015). Evidence shows that, only $4.6 \%$ of both public and private Gross Domestic Product (GDP) in 2017 was committed to the sector (WHO, 2017a, b \& c). Other factors that impede quality health care delivery in Nigeria include inability of the consumer to pay for healthcare services (Sanusi \& Awe, 2015), gender bias due to religious or culture belief and inequality in and inequality the distribution of healthcare facilities between urban and rural areas (Omoruan, Bamidele \& Philips, 2014). 
Specifically, the formulation and implementation of Health Insurance policies across developed countries has great disparity when compared with what is obtainable across developing countries such as Nigeria and Ghana. Affirmatively, the operations and service delivery functions of Health Insurance Scheme in countries of the world such as United State of America, Canada, Britain, France and some African countries such as Kenya, Ruwanda , attest to the viability of administrative structure as fundamental instrument in the determination of goal attainment and policy implementation. These successes recorded in these aforementioned countries are owned largely to policy formulation and implementation procedures, operational structure of the institutions saddled with the basic responsibility of carrying out the stated objectives of the organisation. Also important in this process is the imperatives of constant and constructive reforms of both the policies and institution involved in delivering the services covered in the scheme. (Johnson \& Stockport, 2016).

In most developing countries (including Nigeria and Ghana) poor state of the nations' healthcare system reinforces poverty and squalor to further deteriorate living conditions (Nwosu, 2015). The indispensability of good healthcare system in national development underlies the government's commitment to providing adequate healthcare services since Nigeria attained political independence in 1960 (Ugbaja, 2011). However, the nature of administrative and organisational mechanism of the Health Insurance Scheme has raised the discussion and interrogation of the factor that serve as impediment of access to healthcare facility under the provisions of the scheme by the beneficiary.

Health policy implementation services and institution providers especially National Health Insurance Scheme is a major framework which was established to meet the endless health challenges affecting the majority of Third World Countries with the primary objectives of making health services available promptly to the beneficiaries at affordable cost. The formulation and implementation of National Health Insurance Policy in countries of the world such as United State of America, France, South-Africa is hinged on the availability of well-structured administrative drives, with strict adherence to rules and regulations governing the actualization of those goals. However, the overall need of quality service delivery especially within the framework of government drive to fulfil its mandate of providing subsidized health service to the citizens becomes a task within the purview of administrative and organisational efficiency. The place of quality healthcare for citizens as a fundamental factor for quality engagement with the forces of nature cannot be over-emphasised. Given the importance of this human need, governments across the world have made adequate provisions for providing health services to the citizens at subsidized rate especially those working within government establishments. In fulfilling this objective, government has to put in place health insurance scheme and structured administrative system that will allow for the smooth running of the policies and the constructive implementation of the National Health Insurance Scheme (NHIS) framework.

In meeting the health need of the people through NHIS implementation one important observation is administrative questions which constitute a major challenge in the implementation of organisations policy. This is because the success or failure of administration to a large extent determines the direction of organisational objective which is a functional driver for implementation analysis and institutional reforms which of great consequence in measuring the end product of governmental drives towards impacting the lives of its citizens. The study therefore, examined the effect of operational goals and objectives in implementation of NHIS in Nigeria and Ghana.

\section{Theoretical framework}

\section{Decision making Theory}

Major proponents of this theory include, Herbert Simon, Richard Snyder and Bruck Burton Spain. The theory was developed after the Second World War through their various works (Varma, 1975). The historical account of the approach as given by Varma, reveals that Snyder developed the theory in opposition to the "static analysis" of human action so far adopted in the study of politics by the structuralist and the system theorist. He stated that, the decision making analysis is based as it was on the process analysis which is capable of dealing with dynamic situations. The decision making theory has also been widely applied in the study of international relation and public policy analysis.

Rumki (2014) notes that, there are mainly three important component of decision making-what exactly does a man do when he makes a decision? He is faced with a problem or, for that matter, recognizes a problem. In the second step, he has a number of alternatives, he himself seeks them out or they are presented him and he looks at the alternatives. And the third step is the choosing of one alternative out of the whole lot-that one alternative, which, according to him will give the best result. 
In the Simon's view, the decision process consists of distinct phases, but these phases do not have a simple sequential relationship. They used the same three major phases as Simon, but gave them new names: identification, development and selection. The identification phase (Simon's "intelligence") consists of two routines; the first of these is decision recognition, in which "problems and opportunities" are identified "in the streams of ambiguous, largely verbal data that decision makers receive". The second routine in this phase is diagnosis or "the tapping of existing information channels and the opening of new ones to clarify and define the issues.'

The development phase (Simon's design') serves to define and clarify the options. This phase, too, consists of two routines. The search routine aims at finding ready-made solutions, and the design routine at developing new solutions or modifying ready-made ones. The last phase, the selection phase (Simon's "choice") consists of three routines. The first of these, the screen routine, is only evoked "when search is expected to generate more readymade alternatives than can be intensively evaluated". In the screen routine, obviously suboptimal alternatives are eliminated. The second routine, the evaluation-choice routine, is the actual choice between the alternatives. It may include the use of one or more of three "modes", namely (intuitive) judgment, bargaining and analysis. In the third and last routine, authorization, approval for the solution selected is acquired higher up in the hierarchy.

Snyder (1954) begins with the simple notion that all political action is undertaken by concrete human beings, and that if we want to comprehend the dynamics of his action, we should be prepared to view the world not from our point of view, but from the perspective of the person taking the decision. According to him, decision-making lies at the heart of all political action, administration, organisational policy and therefore, it alone provides the common focus under which we can bring together the political actors, situations and processes for purpose of' analysis. He posits that understanding a particular political action requires the analyst to ascertain who made the decision that resulted in the action and examine the interaction and intellectual factors that influenced the decision- makers.

While applying his postulations to administration, public policy and how decisions are arrived at in matters affecting the generality of the people, he categorized the factors which prompt decision-makers action into three phases, namely: the internal setting, the external setting, the decision making process.

The internal setting within the purview of the NHIS includes the need to provide the limitless health need of the people who have been compounded by the lack of adequate resources that is required to meet their various health need. Furthermore, the external setting in this regard involves the call by supranational organisations such as WHO and other organs of the UN that has been driven by passion for formulating and implementing polices with human face meant to address various gap created by financial challenges caused by underdevelopment and poverty. Finally, in this sense the decision making process involves the various institutions and interactions amongst persons who have the responsibility of addressing societal challenges and consequently raising the standards to solve those problems.

Consequent upon the above, the operationalization, administration and delivery of the services provided by the scheme is largely defined by internal dynamics, the external settings and most fundamentally the decision making process which includes the interest of the decision making elites, the need of the people and finally the resources available in the state for executing the policies when institutionalized.

According to him, the internal setting is the society for which the officials make decisions. It includes such variables of the society such as public opinion; dominate value orientations, organizational dynamics and social structure. The external setting consists of factors such as the actions and reactions of' other actors in the international or national environments and also the physical environment. The forces which make up the decision making processes are the organization division of spheres of competence of decision makers. The motivational factors comprise of the interest which an official acquires in the decision-making organization and the personality traits acquired from childhood. They also include the roles, norms and functions within the government in general and the particular units which the decisions are made. It is important to note that it is the combination of these factors that influences the decision maker in the act and duty of policy formulation.

They further state that the action of the state was regarded as the prime actor in the foreign policy and indeed in international politics and its behavior was always tried to be understood in the objective realities of its position in the world. Snyder (1954) argues also that the state action was, after all, the action of its officials and officials acted according to what they regarded as the "objective circumstances". 


\section{Methodology:-}

The study adopted survey research design. By this method, the researcher used both structured questionnaire and interview guide to obtain data from a sample of population in order to make generalization on the purpose of the study. The survey research design was used to solicit information from the respondents. The main independent variable in this research is the administration of National Health Insurance Scheme. The population of the study was 4,786,990 (see Table 4.1). These are individuals and health facilities registered under NHIS in Nigeria and Ghana. This study selected five states in Nigeria (Lagos, Abuja, Edo, Imo and Ogun States) and three regions in Ghana (Ashanti, Brong-Ahafo, and Greater Accra regions) the justification for the Ghana is that those three regions are one of the largest regions in Ghana. Taro Yamane was used to determine the sample size of 400. Questionnaire and interview guide were the instruments for data collection. Descriptive and inferential statistics were employed in the analysis of data.

\section{Results and Discussion:-}

Table 1:-Goals and Objectives of NHIS in Nigeria and Ghana

\begin{tabular}{|c|c|c|c|c|c|c|c|c|c|}
\hline \multirow[t]{2}{*}{$\mathbf{S} / \mathbf{N}$} & \multirow[t]{2}{*}{ Statements } & & SA & $\mathbf{A}$ & D & SD & $\mathbf{U}$ & Mean & SD \\
\hline & & & $\mathbf{F}(\%)$ & $\mathbf{F}(\%)$ & $\mathbf{F}(\%)$ & $\mathbf{F}(\%)$ & $\mathbf{F}(\%)$ & & \\
\hline \multirow[t]{2}{*}{1} & \multirow{2}{*}{$\begin{array}{l}\text { High standard of } \\
\text { healthcare services } \\
\text { is impossible with } \\
\text { current NHIS policy }\end{array}$} & $\begin{array}{l}\text { Nigeria } \\
(\mathrm{N}=169)\end{array}$ & $\begin{array}{l}41 \\
(24.3)\end{array}$ & $\begin{array}{l}52 \\
(30.8)\end{array}$ & $\begin{array}{l}45 \\
(26.6))\end{array}$ & $\begin{array}{l}16 \\
(9.5)\end{array}$ & $15(8.9)$ & 3.52 & 1.22 \\
\hline & & $\begin{array}{l}\text { Ghana } \\
(\mathrm{N}=209)\end{array}$ & $\begin{array}{l}52 \\
(24.9)\end{array}$ & $\begin{array}{l}80 \\
(38.3)\end{array}$ & $\begin{array}{l}58 \\
(27.8)\end{array}$ & $\begin{array}{l}9 \\
(4.3)\end{array}$ & $\begin{array}{l}10 \\
(4.8)\end{array}$ & 3.74 & 1.03 \\
\hline \multirow[t]{2}{*}{2} & \multirow{2}{*}{$\begin{array}{l}\text { Greater integration } \\
\text { of private sector } \\
\text { health institutions in } \\
\text { the nation's } \\
\text { healthcare system is } \\
\text { possible because of } \\
\text { accurate current } \\
\text { NHIS policy }\end{array}$} & $\begin{array}{l}\text { Nigeria } \\
(\mathrm{N}=169)\end{array}$ & $\begin{array}{l}39 \\
(23.1)\end{array}$ & $\begin{array}{l}56 \\
(33.1)\end{array}$ & $\begin{array}{l}52 \\
(30.8)\end{array}$ & $\begin{array}{l}7 \\
(4.1)\end{array}$ & $\begin{array}{l}15 \\
(8.9)\end{array}$ & 3.57 & 1.15 \\
\hline & & $\begin{array}{l}\text { Ghana } \\
(\mathrm{N}=209)\end{array}$ & $\begin{array}{l}48 \\
(23.0)\end{array}$ & $\begin{array}{l}70 \\
(33.5)\end{array}$ & $\begin{array}{l}62 \\
(29.7)\end{array}$ & $\begin{array}{l}8 \\
(3.8)\end{array}$ & $\begin{array}{l}21 \\
(10 .)\end{array}$ & 3.56 & 1.18 \\
\hline \multirow[t]{2}{*}{3} & \multirow{2}{*}{$\begin{array}{l}\text { Availability of } \\
\text { funds to the health } \\
\text { sector is not } \\
\text { sufficient due to } \\
\text { current NHIS }\end{array}$} & $\begin{array}{l}\text { Nigeria } \\
(\mathrm{N}=169)\end{array}$ & $\begin{array}{l}46 \\
(27.2)\end{array}$ & $\begin{array}{l}42 \\
(24.9)\end{array}$ & $\begin{array}{l}45 \\
(26.6)\end{array}$ & $\begin{array}{l}20 \\
(11.8)\end{array}$ & $\begin{array}{l}16 \\
(9.5)\end{array}$ & 3.49 & 1.27 \\
\hline & & $\begin{array}{l}\text { Ghana } \\
(\mathrm{N}=209)\end{array}$ & $\begin{array}{l}57 \\
(27.3)\end{array}$ & $50(23.69)$ & $54(25.8)$ & $25(12.0)$ & $23(11.0)$ & 3.44 & 1.30 \\
\hline \multirow[t]{2}{*}{4} & \multirow{2}{*}{$\begin{array}{l}\text { Access to good } \\
\text { healthcare services } \\
\text { for all is achieved } \\
\text { with current NHIS } \\
\text { Policy }\end{array}$} & $\begin{array}{l}\text { Nigeria } \\
(\mathrm{N}=169)\end{array}$ & $\begin{array}{l}33 \\
(19.5)\end{array}$ & $\begin{array}{l}61 \\
(36.1)\end{array}$ & $\begin{array}{l}42 \\
(24.9)\end{array}$ & $\begin{array}{l}23 \\
(13.6)\end{array}$ & $\begin{array}{l}10 \\
(5.9)\end{array}$ & 3.50 & 1.13 \\
\hline & & $\begin{array}{l}\text { Ghana } \\
(\mathrm{N}=209)\end{array}$ & $\begin{array}{l}39 \\
(18.7)\end{array}$ & $\begin{array}{l}68 \\
(32.5)\end{array}$ & $\begin{array}{l}52 \\
(24.9)\end{array}$ & $\begin{array}{l}32 \\
(15.3)\end{array}$ & $\begin{array}{l}18 \\
(8.6)\end{array}$ & 3.37 & 1.20 \\
\hline \multirow[t]{3}{*}{5} & \multirow{2}{*}{$\begin{array}{l}\text { Equitable } \\
\text { distribution of } \\
\text { healthcare costs and } \\
\text { facilities are } \\
\text { properly done due } \\
\text { to current NHIS } \\
\text { policy }\end{array}$} & $\begin{array}{l}\text { Nigeria } \\
(\mathrm{N}=169)\end{array}$ & $\begin{array}{l}31 \\
(18.3)\end{array}$ & $\begin{array}{l}50 \\
(29.6)\end{array}$ & $\begin{array}{l}48 \\
(28.4)\end{array}$ & $\begin{array}{l}28 \\
(16.6)\end{array}$ & $\begin{array}{l}12 \\
(7.1)\end{array}$ & 3.36 & 1.17 \\
\hline & & $\begin{array}{l}\text { Ghana } \\
(\mathrm{N}=209)\end{array}$ & $\begin{array}{l}39 \\
(18.7)\end{array}$ & $\begin{array}{l}61 \\
(29.2)\end{array}$ & $\begin{array}{l}60 \\
(28.7)\end{array}$ & $\begin{array}{l}34 \\
(16.3)\end{array}$ & $\begin{array}{l}15 \\
(7.2)\end{array}$ & 3.36 & 1.17 \\
\hline & Mean and SD & & & & & & & 3.49 & .767 \\
\hline
\end{tabular}

Source: Field Survey, 2018.

$(\mathrm{N}=378)$ Cut-off point $=3.5$

As indicated in Table 5.6, the mean for the goals and objectives of NHIS in Nigeria and Ghana was 3.49 with a standard deviation of 0.76. The results indicate that the following were the most important goals and objectives of NHIS in Nigeria and Ghana: achieving high standard of healthcare services in Nigeria $(\mathrm{X}=3.52, \mathrm{SD}=1.22)$ and 
Ghana $(X=3.74, \mathrm{SD}=1.03)$; greater integration of private sector health institutions in the nation's healthcare system, Nigeria $(X=3.57$., $S D=1.15)$ and Ghana $(X=3.56, S D=1.18)$. While gaining access to good healthcare services for all was seen very relevant only in Nigeria $(X=3.50 \mathrm{SD}=1.13)$ but was not seen as very important in $\mathrm{Ghana}(\mathrm{X}=3.37$, $\mathrm{SD}=1.20)$. Availability of funds to the health sector in both Nigeria $(X=3.49, \mathrm{SD}=1.27)$ and $\mathrm{Ghana}(\mathrm{X}=3.44$, $\mathrm{SD}=1.30)$ and equitable distribution of healthcare costs and facilities in Nigeria $(\mathrm{X}=3.36, \mathrm{SD}=1.17)$ and $\mathrm{Ghana}$ $(\mathrm{X}=3.36, \mathrm{SD}=1.17)$ were not mostly considered as goals and objectives of NHIS. This indicates that there is a need to broaden the goals and objectives of NHIS to incorporate elements of costs and facilities of healthcare, funding and access.

The fifth question examined the goals and objectives of NHIS in Nigeria and Ghana. As indicated in the results, the most important goals and objectives of NHIS in Nigeria and Ghana: achieving high standard of healthcare services and greater integration of private sector health institutions in the nation's healthcare system. However, availability of funds to the health sector, gaining access to good healthcare services for all and equitable distribution of healthcare costs and facilities were not mostly considered as goals and objectives of NHIS, implying urgent need broaden the goals and objectives of NHIS to incorporate elements of costs and facilities of healthcare, funding and access. Therefore, the success of NHIS is largely a function of its formulation procedures, implementation mechanisms, administrative and management techniques. These factors underscore the level of success that will be achieved and how much impact the NHIS scheme will make on its beneficiaries.

\section{Test of hypothesis}

Ho: There is no significant influence of the goals and objectives of NHIS on its implementation in Ghana and Nigeria

Table 2:-A Summary of linear regression analysis showing the influence of Goals and objectives of NHIS on implementation in Nigeria and Ghana

\begin{tabular}{|c|c|c|c|c|c|}
\hline \multirow[b]{2}{*}{ Predictor } & \multicolumn{2}{|c|}{ Unstandardized Coefficients } & \multirow{2}{*}{$\begin{array}{l}\text { Standardized coefficients } \\
\text { Beta }\end{array}$} & \multirow[b]{2}{*}{$\mathbf{T}$} & \multirow[b]{2}{*}{ Sig } \\
\hline & B & Standard Error & & & \\
\hline (Constant) & 1.978 & .179 & \multirow[t]{2}{*}{.453} & 11.037 & .000 \\
\hline $\begin{array}{l}\text { Goals and } \\
\text { objectives of NHIS }\end{array}$ & .494 & .050 & & 9.843 & .000 \\
\hline
\end{tabular}

Source: Field Survey, 2018.

$R=.453, R^{2}=.205$, Adj $R^{2}=.203, F(1,376)=96.890$

Table 4.8 showed the influence of Goals and objectives of NHIS on its implementation in Nigeria and Ghana. The result of linear regression showed that goals and objectives of NHIS are factors that determine NHIS implementation in Nigeria and Ghana $(\beta=.453, p<.05)$ indicating that for every one goal and objective introduced, NHIS implementation increases by 0.453 holding everything else fixed. This implies that setting of more goals and objectives for NHIS will be predictive of higher level of NHIS implementation in Nigeria and Ghana Furthermore, the results revealed that the setting of goals and objectives for NHIS explained $20.5 \%$ of the variance in NHIS implementation $\left(R^{2}=0.205, p<.05\right)$. Therefore, the hypothesis that goals and objectives of NHIS will not be factors that determine NHIS implementation in Nigeria and Ghana is rejected.

Hypothesis three examined the impact of goals and objectives of NHIS on NHIS implementation in Nigeria and Ghana. This was tested using simple linear regression analysis. The result of linear regression showed that goals and objectives of NHIS were factors that determine NHIS implementation in Nigeria and Ghana indicating that for every one more additional goal and objective introduced, NHIS implementation increases by 0.453 holding everything else fixed. This implies that setting of more goals and objectives for NHIS will be predictive of higher level of NHIS implementation in Nigeria and Ghana. Infact, the setting of goals and objectives for NHIS explained $20.5 \%$ of the variance in NHIS implementation. This explains the importance of broadening the goals and objectives of the schemes in order to produce more meaningful results. When meaningful goals and objectives are set for the scheme, this tends to enable more implementation of healthcare programs that support utilization of NHIS resources. 


\section{Conclusion and Recommendations:-}

The findings of this study indicated that goals and objectives of the schemes do act as factors that affect implementation. The goals and objectives as having a relationship and influential in affecting the implementation of NHIS has not been fully employed within the schemes as it was shown that implementation of the schemes is low indicating an area for the attention of stakeholders. Therefore, NHIS policy and legislations should be reconsider to address operations and service delivery of NHIS on the extent to which their work activities are shaped and maintained by these policies and legislations.

Government should incorporate efficient methods for implementation of the scheme so that each enrolee can maximally access health care when they need to and provide platforms and infrastructure that aid efficient operations and service delivery of the scheme for continuous development of the entire programs of the scheme.

NHIS should facilitate access to the scheme and its facilities for enrolees' use by providing policy that makes information about the scheme publicly available. This is not usually possible in Nigeria where information about total enrolees is not publicly available. NHIS mandate its agencies to incorporate effective implementation of its policies including goals and objectives into the work processes as one of the requirements for decision health care delivery. NIHS facilitate the establishment of health information sharing networks and platforms that aid access to the scheme (such as databank and statistical centers) at both the regional and national level.

\section{References:-}

1. Anifowose, R. \& Enemuo, F. (2015). Element of Politics. Lagos: Sam Iroanusi Publications.

2. Federal Ministry of Health (FMH) (2017). The National Health Policy and Strategy to Achieve Health for all. Abuja: FMH.

3. FMH (2017). Operational Guideline of National Health Insurance Scheme. Abuja: FMH.

4. Hepnet, K. (2017). Health economics and policy network in Africa: The Implementation of the National Health Insurance Scheme (NHIS) Ghana: Experience Sharing.

5. Johnson, J.A. \& Stoskopf, C. (2016). Comparative health systems: Global perspectives. Massachusetts: Jones and Bartlett Publishers.

6. National Health Insurance Scheme (NHIS) (2017). National Health Insurance Scheme. Retrieved from http://www.nhis.goving.

7. NHIS (2014). National Health Insurance Scheme. Retrieved from http://www.nhis.goving.

8. NHIS (2012). National Health Insurance Scheme handbook. Abuja: Government Press.

9. National Health Insurance Scheme Decree No. 35 of 1999. Online available at http://www.nigerialaw.org/NationalHealthInsuranceSchemeDegree.ht m. Retrieved on March 23, 2018.

10. NCBI (2014). Gender Bias in Access to Healthcare in Nigeria: A study of End- State Renal Disease. Online available at: http://www.ncbi.nlm.nih.gov/pubmed/18302871?dopt=Abstractplus Retrieved March, 23, 2018.

11. Nwosu, A.B.C (2015). Healthcare financing in Nigeria; 2000-2003. Medical Journal, 21(3), 1-12.

12. Oba, J. O. (2015). Nigeria: Yar'Adua and the Resuscitation of Health Sector. Online available at: http://allatrica.com/stories/200806021431.html. Retrieved March, 23, 2018.

13. Ogundiwin, A. O. (2015). Selected theories and their application to political science research in Nwachukwu, J. N., Ogundiwin, A. O. and Nwaobia, A. N (ed.) Anthology of Theories and their Application in Social and Management Sciences. Lagos: Jamiro Press Link.

14. Rumki, B. (2014). Public Administration Concept and Theories. New Delhi: Sterling Publishers PrivateLimited.

15. Sanusi, R. A. \& Awe, A. T. (2015). Perception of National Health Insurance Scheme (NHIS) by Health Care Consumers in Oyo State, Nigeria. Pakistan Journal of Social Sciences, 6 (1), 48-53.

16. Synder, et al (2013). The decision makingaprroach to the study of international politics. In James N. R. (ed.), International Politics and Foreign Policy. A Reader in Research and Theory. New York: Free Press.

17. Ugbaja, C.O (2011). Alternative method of healthcare financing. Community Medicine. Oct - Dec. Vol.1, 19-30.

18. Yohersor, A. (2014). Social health insurance scheme that works: Recommendation to NHIS. Abuja: V.C Publishers. 